\title{
OBSERVATIONS ON THE REPRODUCTIVE BIOLOGY OF ROUNDTAIL CHUB, GILA ROBUSTA, IN THE UPPER VERDE RIVER, ARIZONA
}

\author{
Mark J. Brouder ${ }^{1,2}$, Diana D. Rogers ${ }^{1}$, and Lorraine D. Avenetti ${ }^{1}$
}

Key words: Roundtail chub, spawning, Verde River.

Status and distribution of native fishes in North America are declining at an alarming rate (Miller et al. 1989, Warren et al. 2000), and understanding life history is a critical step in identifying and evaluating necessary conservation measures to better manage or recover a species. Roundtail chub, Gila robusta, is 1 such species whose status and distribution are declining in Arizona (Voeltz 2002) and throughout much of its historic range. Increasing our knowledge and understanding of its reproductive biology may provide insight into the rea$\operatorname{son}(\mathrm{s})$ for this species' decline and how to potentially reverse the trend. Objectives of this study were to determine time of spawning by roundtail chub, estimate fecundity, and quantify spawning habitat.

Roundtail chub were collected monthly from January 1998 through December 1998 at 5 sites within the upper Verde River, Arizona, using primarily a Smith-Root ${ }^{\circledR}$ backpack shocker; seines, hoop nets, trammel nets, and angling were also used. After capture, total length (TL) and total weight (TW) were determined and fish were sacrificed and preserved for later processing in the laboratory. Fish were sexed based on presence of testes or ovaries. Ovaries were removed from females, blotted dry, and weighed to the nearest $0.1 \mathrm{~g}$ to obtain ovary weight $(\mathrm{OW})$; ovary-free body weight $(\mathrm{OFBW})$ was determined by the following expression: TW - OW. Gonadosomatic index (GSI) of female roundtail chub was calculated as $100 \cdot \mathrm{OW} /$ OFBW and plotted against capture month to estimate time of spawning. Egg counts were made from approximately one-third samples of each ovary from females collected during the 2 sampling events immediately prior to presumed peak spawning based on GSI results. Fecundity (FE) was calculated using the proportion of sample weight to weight of all eggs in the ovaries. Regression equations determined the relationships between FE and TL, and between FE and TW.

Observations of roundtail chub spawning were conducted between 0600 hours and 1800 hours on 16 May and 17 May 1998, following collection of ripe males and females at this same site 1 day prior. When spawning was observed, depth $(\mathrm{cm})$, velocity $\left(\mathrm{cm} \cdot \mathrm{s}^{-1}\right)$, and temperature $\left({ }^{\circ} \mathrm{C}\right)$ were measured at the mid-depth of the water column; and dominant substrate at 5 points along a transect perpendicular to shore was visually determined to describe roundtail chub spawning habitat. Depth and current velocity were measured using a MarshMcBirney portable electronic current meter attached to a wading rod. Temperature was measured using a handheld thermometer. Roundtail chub spawning habitat was characterized using transect means and percentage of dominant substrate, and classified as pool, riffle, or glide (Helm 1985).

A total of 207 roundtail chub collected from the upper Verde River comprised 73\% (151) males and 27\% (56) females for an approximate 3:1 ratio. Males averaged $277 \mathrm{~mm}$ TL (range 204-364 mm, $s_{\bar{x}}=3.6$ ) and $176 \mathrm{~g}$ (range 63-401 g, $s_{\bar{x}}=7.2$ ); females averaged $329 \mathrm{~mm}$ TL (range $249-427 \mathrm{~mm}, s_{\bar{x}}=11.1$ ) and $380 \mathrm{~g}$ (range $=132-836 \mathrm{~g}, s_{\bar{x}}=48.2$ ).

Mean GSI for female roundtail chub was highest in April followed by a sharp decrease in May, indicating that peak spawning likely occurred over $\sim 1$ month (Fig. 1). The lowest mean GSI for female roundtail chub was in September.

\footnotetext{
${ }^{1}$ Arizona Game and Fish Department, Research Branch, 2221 West Greenway Road, Phoenix, AZ 85023.

${ }^{2}$ Present Address: U.S. Fish and Wildlife Service, Arizona Fishery Resources Office, Box 39, Pinetop, AZ 85935.
} 


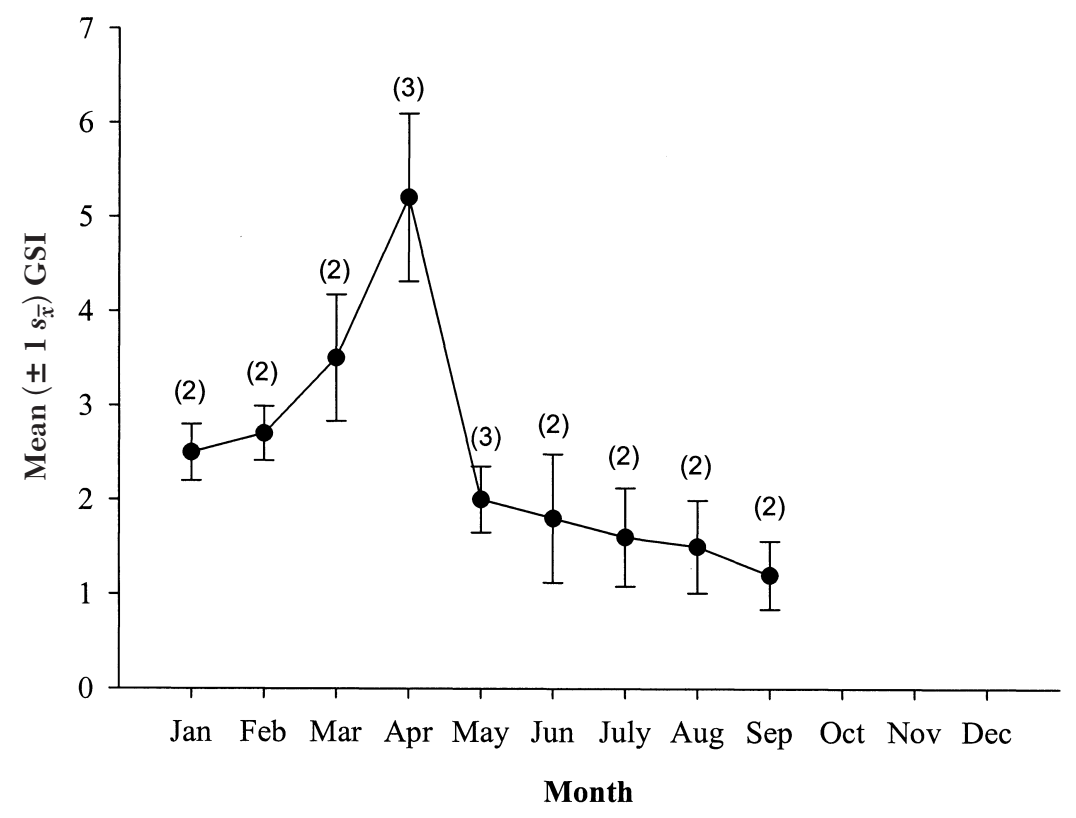

Fig. 1. Mean gonadosomatic index (GSI) values by month of capture for female roundtail chub from the upper Verde River, Arizona, 1998. Numbers in parentheses represent sample sizes.

The mean fecundity of female roundtail chub was 18,699 eggs (range 13,816-26,903 eggs, $s_{\bar{x}}$ $=2549.1, n=5)$. Fecundity was correlated with increasing total weight $\left(F=52.8, r^{2}=\right.$ $0.839, P<0.0001$ ); the relationship between fecundity and total length was also significant $\left(F=4.3, r^{2}=0.234, P=0.033\right)$. The fecundity to total weight relationship was $\mathrm{FE}=25.3(\mathrm{TW})$ +328 .

Twenty-three and 19 separate spawning events were observed on 16 May and 17 May 1998, respectively, occurring between 1115 hours and 1445 hours each day. Spawning events included 1 large female flanked by 2 or 3 smaller males (approximately one-half to twothirds the length of the female) with their vents in close proximity to each other. The female would rapidly "quiver" her caudal region while the males followed suit, pressing their bodies against the female. Spawning events lasted from 4 to 10 seconds and took place near the base of a riffle. Adhesive eggs were laid over clean gravel (which comprised $78 \%$ of the overall substrate) in water with a mean depth of $31.6 \mathrm{~cm}$, current velocity of $43.8 \mathrm{~cm} \cdot \mathrm{s}^{-1}$, and temperature of $18.3^{\circ} \mathrm{C}$. Eggs $(n=39)$ recovered from the gravel averaged $2.7 \mathrm{~mm}$ in diameter (range 1.8-3.8 $\mathrm{mm}, s_{\bar{x}}=0.6$ ).
Based on mean GSI values of females, roundtail chub in the upper Verde River spawned mainly between mid-April and midMay, $\sim 1$ month earlier than reported for roundtail chub in the Upper Colorado River, Colorado (Kaeding et al. 1990) and the Yampa and Green rivers, Colorado and Utah (Karp and Tyus 1990). This is likely a result of the Verde River warming earlier in the year than more northern sites. Mature males and females were also smaller in average TL than those reported by Kaeding et al. (1990) and Karp and Tyus (1990). Because estimated GSI and fecundity of Verde River roundtail chub were obtained from comparatively few fish collected in a single year, it is difficult to determine if our results represent average conditions or if they are a result of a particularly "good" or "bad" year during which this study was conducted.

Neve (1976) also observed roundtail chub spawning in "pool-riffle" habitat in Fossil Creek, Arizona, and, although Bestgen and Propst (1989) did not observe roundtail chub spawning, a large aggregation of ripe males and females was observed in a pool just below a riffle in the East Fork of the Gila River, New Mexico. 
The timing and temperature of roundtail chub spawning observed in this study (16-17 May $1998,18.3^{\circ} \mathrm{C}$ ) and the range of roundtail chub spawning temperatures observed by Kaeding et al. $\left(1990 ; 14^{\circ}-20^{\circ} \mathrm{C}\right)$ overlap those of resident nonnative largemouth bass Micropterus salmoides $\left(18^{\circ}-22^{\circ} \mathrm{C}\right)$ and smallmouth bass $M$. dolomieu $\left(16^{\circ}-20^{\circ} \mathrm{C}\right.$; Jenkins and Burkhead 1993). Other nonnative fishes in the upper Verde River (green sunfish, Lepomis cyanellus; yellow bullhead, Ameiurus natalis; channel catfish, Ictalurus punctatus; and flathead catfish, Pylodictis olivaris) spawn when temperatures approach $21^{\circ}-22^{\circ} \mathrm{C}$. Overlap in time of spawning may result in larval roundtail chub, largemouth bass, and smallmouth bass experiencing some level of direct or indirect resource competition.

Our results suggest that roundtail chub in the upper Verde River found suitable spawning habitat in a pool-riffle complex containing clean gravel; maintenance of this type of habitat may be important for the conservation of this species. Minimization of impacts from land-use practices (e.g., logging, road construction, grazing, etc.) that reduce the quality and quantity of pool-riffle habitat would help maintain suitable spawning habitat of roundtail chub.

We thank Scott Bonar, Scott Bryan, Bill Persons, and 3 anonymous reviewers for reviewing and improving upon an earlier draft of this manuscript. Funding was provided by the Sportfish Restoration Fund administered through the Arizona Game and Fish Department (Project F-4-R).

\section{Literature Cited}

Bestgen, K.R., And D.L. Propst. 1989. Distribution, status, and notes on the ecology of Gila robusta (Cyprinidae) in the Gila River drainage, New Mexico. Southwestern Naturalist 34:402-412.

HeLm, W.T. 1985. Aquatic habitat inventory: glossary and standard methods. American Fisheries Society, Western Division, Bethesda, MD.

Jenkins, R.E., AND N.M. Burkhead. 1993. Freshwater fishes of Virginia. American Fisheries Society, Bethesda, MD.

Kaeding, L.R., B.D. Burdick, P.A. Schrader, and C.W. MCADA. 1990. Temporal and spatial relations between the spawning of humpback chub and roundtail chub in the Upper Colorado River. Transactions of the American Fisheries Society 119:135-144.

Karp, C.A., AND H.M. Tyus. 1990. Humpback chub (Gila cypha) in the Yampa and Green Rivers, Dinosaur National Monument, with observations on roundtail chub (G. robusta) and other sympatric fishes. Great Basin Naturalist 50:257-264.

Miller, R.R., J.D. Williams, and J.E. Williams. 1989. Extinctions in North American fishes during the past century. Fisheries 14:22-38.

Neve, L.L. 1976. Life history of the roundtail chub Gila robusta grahami, at Fossil Creek, Arizona. Master's thesis, Northern Arizona University, Flagstaff.

Voeltz, J.B. 2002. Roundtail chub (Gila robusta) status survey of the Lower Colorado River basin. Nongame and Endangered Wildlife Program Technical Report 186, Arizona Game and Fish Department, Phoenix.

Warren, M.L., Jr., B.M. BurR, S.J. Walsh, H.L. Bart, R.C. Cashner, D.A. Etnier, B.J. Freeman, et al. 2000. Diversity, distribution, and conservation status of the native freshwater fishes of the southern United States. Fisheries 25(10):7-29.

Received 20 December 2004 Accepted 12 July 2005 